\title{
POLA REKRUTMEN CALON ANGGOTA LEGISLATIF OLEH DPC PARTAI DEMOKRAT KABUPATEN POLMAN PROVINSI SULAWESI BARAT PADA PEMILU 2014
}

Ishaq $^{1}$, Jaelan Usman ${ }^{2}$, Andi Luhur Prianto ${ }^{3}$

Program Studi Ilmu Pemerintahan Fakultas Ilmu Sosial Dan Ilmu Politik Universitas Muhammadiyah Makassar Jl. Sultan Alaudin No. 259 Makassar 90221 Tlp. 0411-866972 ext. 107. Fax. 0411-8655888

\section{ABSTRACT}

This study aimed to describe the recruitment pattern of candidates for the legislative Democrats DPC Polman, West Sulawesi province, as well as describe the steps taken by the DPC in the determination of the Democratic Party legislative candidates in Polman, West Sulawesi province. The research methods used by the author in this study is descriptive qualitative using two kinds of data, namely, primary and secondary data. The data were analyzed descriptive qualitatively in which analyzing all the data collected subsequent authors and presented in the form of frequency tabulation equipped with informants responses obtained from interviews and questionnaire results obtained from 30 respondents. The results showed that the recruitment of candidates for the legislative pattern used by Democrats DPC is an open recruitment. The steps taken by the DPC Democrats are: Preparation, at this stage, the Democratic Party to set up some things for recruitment legislative candidates, such as team building and tasks of the team themselves. Announcement, the Democratic Party announced the registration of legislative candidates. Registration, registrants at this stage were distributed forms to be filled out and returned with all the files required. Verification, at this stage all applicants files were selected as required by the Democrats party. Special selection, at this stage, the party gave fit and proper test. Tasking, at this stage all candidates are given the task on the field to socialize directly to the public. Evaluation and final assessment, at this stage, the candidates were given the final assessment to determine the legislative candidates. Determining legislative candidates, at this stage, to establish a working meeting party legislative candidates to be submitted to the Commission.

Keywords: recruitment patterns, legislative, general elections. 


\section{ABSTRAK}

Penelitian ini bertujuan untuk menggambarkan pola rekrutmen calon anggota legislatif DPC Partai Demokrat Kabupaten Polman Provinsi Sulawesi Barat, serta menggambarkan langkah-langkah yang ditempuh oleh DPC Partai Demokrat dalam penetapan calon anggota legislatif di Kabupaten Polman Provinsi Sulawesi Barat. Metode penelitian yang digunakan penulis dalam penelitian ini adalah deskriptif-kualitatif dengan menggunakan dua macam data yaitu, data primer dan data skunder. Data tersebut dianalisis secara deskripti kualitatif yaitu menganalisis semua data yang berhasil dikumpulkan penulis dan selanjutnya disajikan dalam bentuk tabulasi frekuensi dilengkapi dengan tanggapan informan yang diperoleh dari hasil wawancara dan hasil kuesioner yang diperoleh dari 30 responden. Hasil penelitian menujukkan bahwa pola rekrutmen calon anggota legisltif yang digunakan oleh DPC Partai Demokrat adalah rekrutmen terbuka. Adapun langkah-langkah yang ditempuh oleh DPC Partai Demokrat yaitu: Persiapan, pada tahap ini Partai Demokrat menyiapkan beberapa hal untuk melakukan rekrutmen calon anggota legislatif, seperti pembentukan tim dan tugas-tugas tim itu sendiri. Pengumuman, dalam Partai Demokrat mengeluarkan Pengumuman mengenai pendaftaran calon anggota legislatif. Pendaftaran, pada tahap ini pendaftar dibagikan formulir untuk diisi dan diserahkan kembali beserta berkas-berkas yang harus dilengkapi. Verifikasi, pada tahap ini semua berkas pendaftar diseleksi kembali sesuai dengan yang dipersyaratkan oleh Partai Demokrat. Seleksi khusus, pada tahap ini Partai melakukan penyeleksian melalui uji kepatutan dan kelayakan. Penugasan, pada tahap ini semua bakal calon diberikan tugas dilapangan untuk terjun langsung ke masyarakat. Evaluasi dan penilaian akhir, pada tahap ini diberikan penilain akhir untuk menetapkan calon anggota legislatif. Penetapan calon anggota legislatif, pada tahap ini dilakukan rapat kerja partai untuk menetapkan calon anggota legislatif yang akan diserahkan ke KPU.

Kata kunci: pola rekrutmen, anggota legislatif, pemilihan umum.

\section{A. PENDAHULUAN}

Tonggak demokrasi di Indonesia resmi ditancapkan. Pergolakan massa yang dimotori mahasiswa pada waktu itu membuat semuanya berubah. Jatuhnya rezim orde baru, bukan saja telah membuka peluang bagi kehidupan politik bangsa Indonesia, tetapi juga menum-buhkan hasrat para tokoh politik untuk dapat menggapai kekuasaan lewat partai politik. Mundurnya Soeharto dari kursi kepresidenan menandai dimulainya babak baru kehidupan politik di negeri ini. Harapan akan terciptanya kehidupan politik nasional yang demokratis begitu kuat menancap dibenak publik. Secara legal formal, orde baru tumbang dan berganti suatu sistem baru bertajuk "Reformasi". Pada masa reformasi ini, pembatasan selama puluhan tahun mereduksi aspirasi politik ke dalam tiga partai poltik, yaitu Partai Golkar, Partai Persatuan Pembangunan (PPP), Partai Demokrasi Indonesia (PDI), tak mampu lagi dipertahankan. Euforia politik yang mewarnai masa-masa itu diwujudkan melalui pendirian partai politik yang jumlahnya puluhan bahkan ratusan.
Maka, kehidupan politik pun memasuki babak baru yang penuh gairah. Hanya waktu satu tahun, sebanyak 181 partai politik hadir dan menyatakan diri siap mengikuti pemilihan umum 1999. Semua berlomba untuk mengisi kevakuman pemimpin nasional (Tobing, 2009 :1).

Berdasarkan Undang-Undang Partai Politik Nomor 2 tahun 2011 pasal 2 tentang pembentukan partai politik perubahan atas UndangUndang Nomor 2 tahun 2008 yang menyatakan Partai Politik didirikan dan dibentuk oleh paling sedikit tiga puluh orang warga negara Indonesia yang telah berusia 21 (dua puluh satu) tahun atau sudah menikah dari setiap provinsi. Partai Politik didaftarkan oleh paling sedikit lima puluh orang pendiri yang mewakili seluruh pendiri Partai Politik dengan akta notaris. Pendirian dan pembentukan Partai Politik menyertakan tiga puluh perseratus keterwakilan perempuan. Akta notaris harus memuat Anggaran Dasar dan Anggaran Rumah Tangga serta kepengurusan Partai Politik tingkat pusat. 
Partai politik dimasa reformasi ini telah membuka peluang masyarakat mendirikan partai, sehingga menghadapi tiga pemilihan umum yang diselenggarakan secara demokratis (tahun 1999, 2004 dan 2009) yang telah menjadi tempat seleksi alam bagi partai politik. Partai yang besar kuat akan tetap hidup sementara yang kecil dan lemah akan tersingkir dengan sendirinya. Terbukti pada pemilu 2009 yang lalu, dari puluhan partai politik yang ada, hanya ada beberapa partai politik yang berhasil memenuhi ambisinya untuk memenangi pertarungan perebutan kekuasaan. Partai Golkar, Gerindra, Hanura, PPP, PKB, PAN, PDIP, PKS dan Partai Demokrat adalah partai politik yang berhasil yang mendominasi peta politik nasional di badan legislatif dan eksekutif. Satu lagi perubahan besar pada perpolitikan Indonesia adalah dengan adanya sistem pemilu yang diadakan secara langsung.

Setiap partai politik memiliki pola rekrutmen yang berbeda, dimana pola perekrutan anggota partai disesuaikan dengan sistem politik yang dianutnya. Selain merekrut, di dalam tubuh partai politik perlu dikembangkan sistem pendidikan dan kaderisasi kaderkader politiknya. Rekrutmen ini dikatakan sebagai persoalan penting mengingat perlu adanya transfer pengetahuan politik, tidak hanya yang terkait dengan sejarah, misi, visi, dan strategi partai politik, tetapi juga hal-hal yang terkait dengan permasalahan bangsa dan negara. Dalam sistem kaderisasi juga dapat dilakukan transfer keterampilan dan keahlian berpolitik. Tugas utama yang diemban oleh partai politik dalam hal ini adalah menghasilkan calon-calon pemimpin berkualitas yang nantinya akan 'diadu' dengan partai lain melalui mekanisme pemilu.

Untuk itu, sangat perlu bagi partai politik, terutama para ketua umumnya, untuk segera memikirkan langkah-langkah strategis yang bisa merubah keadaan ini. Mereka harus melakukan perombakan mendasar terhadap sistem rekrutmen politik di dalam partai politik yang mereka pimpin sehingga bisa mendukung proses kaderisasi nasional (Firmanzah, 2011 : 71-72).

Dalam Undang-Undang Pemilihan Umum Anggota DPR, DPD, dan DPRD Nomor 8 Tahun
2012 Pasal 51 tentang persyaratan bakal calon anggota DPR, DPRD Provinsi dan DPRD Kabupaten/Kota di tegaskan bahwa Bakal calon anggota DPR, DPRD Provinsi dan DPRD Kabupaten/Kota adalah Warga Negara Indonesia dan harus memenuhi persyaratanpersyaratan yang terdapat didalamnya.Partai politik tanpa sistem rekrutmen tidak berarti apa-apa, hukum alamnya setiap manusia akan mengalami tua dan penurunan daya kemampuan, begitu juga dengan partai politik, ia membutuhkan regenerasi. Regenerasi pasti dilakukan tetapi untuk memperoleh hasil regenerasi yang baik, maka dibutuhkan proses rekrutmen yang sistematis dan penanganan yang khusus.

Apabila proses rekrutmen ini macet, maka transfer kepemimpinan dari generasi tua kepada generasi yang lebih muda akan macet. Proses rekrutmen dalam partai politik ini telah menimbulkan kekecewaan yang dalam di banyak kalangan. Kekecewaan ini diwujudkan dengan pembentukan partai-partai politik baru dan munculnya wacana perseorangan di tengah keinginan kolektif untuk membangun sebuah sistem demokrasi perwakilan yang memposisikan partai politik sebagai satusatunya agen perubahan.

Untuk itu partai politik dalam merekrut seorang calon anggota legislatif menetapkan beberapa persyaratan dan kriteria tersendri sesuai dengan ideologi partai masing-masing. Seperti halnya partai politik pada umumnya, Partai Demokrat dalam hal memilih calon anggota legislatif haruslah seorang yang mengerti tentang azas, ideologi, peraturan partai dan juga merupakan orang yang benarbenar dikehendaki oleh rakyat. Hal ini dapat dimengerti karena seorang calon anggota legislatif jika terpilih nantinya harus memperjuangkan kepentingan partai yang mengusungnya.

Dengan demikian, ini akan menjamin tetap sterilnya tujuan besar partai dari kepentingan-kepentingan orang yang tidak memahami arah dan perjuangan Partai Demokrat dan Partai Demokrat juga terhindar dari para kutu loncat/oportunis partai.

Namun pada kenyataannya, ada beberapa calon anggota legislatif dari Partai Demokrat 
untuk daerah pemilihan Polewali Mandar (Polman) bukanlah seorang kader atau anggota Partai Demokrat, tetapi berasal dari partai lain. Dari kejadian seperti ini terlihat bahwa rekrutmen calon anggota legislatif Partai Demokrat disinyalir tidak dilakukan atas dasar peraturan dan kriteria yang telah ditetapkan. Dan ini juga membuktikan bahwa pola rekrutmen Partai Demokrat masih tergolong lemah. Hal ini tentu akan merusak pola rekrutmen dan kaderisasi Partai Demokrat dan akan memunculkan kecemburuan pada kader sejati Partai Demokrat.

Penulis tertarik meneliti terhadap persoalan di atas dengan harapan hasil penelitian dapat memberikan hasil dan berguna bagi Kabupaten Polman.

\section{B. KERANGKA TEORITIS}

Partai politik sesungguhnya merupakan sebuah kendaraan, yang fungsinya untuk menyatukan orang-orang yang memiliki visi dan misi yang sama dalam penyelenggaraan negara. Berdasarkan visi dan misi tersebut, partai politik memiliki program-program politik yang dilakukan dengan bersama-sama dari setiap masing-masing anggotanya, serta memiliki tujuan untuk menduduki jabatan politik di pemerintahan.

Menurut Palombara dan Weiner (dalam Sitepu, 2012 : 185), ada tiga teori yang dapat menjelaskan asal usul dan pertumbuhan politik. Pertama, teori kelembagaan yang melihat ada keterhubungan antara parlemen awal dan timbulnya partai politik. Kedua, teori situasi historis yang melihat timbulnya partai politik sebagai upaya suatu sistem politik untuk mengatasi krisis yang ditimbulkan dengan perubahan secara luas. Ketiga, teori pembangunan yang melihat partai politik sebagai produk modernisasi sosial ekonomi.

Dengan semakin meluasnya gagasan bahwa rakyat merupakan faktor yang perlu diperhitungkan dan diikutsertakan dalam proses politik, maka partai politik lahir secara spontan dan berkembang menjadi penghubung antara rakyat disatu sisi dan pemerintah disisi lainya.
Secara umum pengertian partai politik didefenisikan sebagai kumpulan orang yang membentuk sebuah partai yang bertujuan merebut kekuasaan, mempertahankan kekuasaan dengan cara yang legitimasi melalui pemilihan umum. Menurut Budiardjo (2008: 403-404) partai politik adalah suatu kelompok yang terorganisir yang anggota-anggotanya mempunyai orientasi, nilai-nilai, dan cita-cita yang sama. Tujuan kelompok ini ialah untuk memperoleh kekuasaan politik dan merebut kedudukan politik biasanya dengan cara konstitusional, untuk melaksanakan kebijakankebijakan mereka.

Sementara itu, Ranney dan Kendal (dalam Firmanzah, 2011 : 69) mendefinisikan partai politik sebagai grup atau kelompok masyarakat yang memiliki tingkat otonomi tinggi untuk mencalonkan dan terlibat dalam pemilu dengan harapan mendapatkan serta menjalankan kontrol atas birokrasi dan kebijakan publik. Definisi partai politik yang hampir serupa juga diberikan Crowe dan Mayo (dalam Firmanzah, 2011 : 69), mereka mendefenisikan partai politik sebagai institusi yang mengaktifkan dan memobilitasi orang, kepentingan, menyediakan instrumen kompromi dari beragam pendapat, dan memfasilitasi munculnya seorang pemimpin.

Menurut Syafiie (2010 : 142), partai politik adalah sekelompok orang yang memiliki ideologi yang sama, berniat merebut dan mempertahankan kekuasaan dengan tujuan untuk memperjuangkan kebenaran, dalam suatu level (tingkat) negara. Neumann (dalam Budiardjo, 2008 : 404), partai politik adalah organisasi dari aktivis-aktivis politik yang berusaha untuk menguasai kekuasaan pemerintah serta merebut dukungan rakyat melalui persaingan dengan suatu golongan atau golongan-golongan lain yang mempunyai pandangan yang berbeda. Dengan demikian partai politik merupakan perantara yang menghubungkan kekuatan-kekuatan dan ideologi sosial dengan lembaga-lembaga pemerintahan yang resmi dan yang mengkaitkannya dengan aksi politik di dalam masyarakat politik yang lebih luas.

Dalam Undang-Undang Nomor 2 Tahun 2011 Pasal 1 ayat (1) partai politik di defenisi- 
kan organisasi yang bersifat nasional dan dibentuk oleh sekelompok warga negara Indonesia secara suka rela atas dasar kesamaan kehendak dan cita-cita untuk memperjuangkan dan membela kepentingan politik anggota, masyarakat, bangsa dan negara, serta memelihara keutuhan Negara Kesatuan Republik Indonesia berdasarkan pancasila dan UndangUndang Dasar Negara Republik Indonesia Tahun 1945.

Sebagian besar partai politik memenangkan pemilu di Indonesia masuk ke dalam kategori partai Catch-all. Dalam hal ini Partai Demokrat termasuk ke dalam model partai Catch-all. Partai Catch-all merupakan gabungan dari partai kader dan partai massa, partai Catch-all diartikan sebagai menampung kelompok-kelompok sosial sebanyak mungkin untuk dijadikan anggotanya. Sebagai partai Catch-all, Partai Demokrat memang hidup dengan tidak mengandalkan ideologi, namun penguatan pada kuantitas basis massa. Selama ini mekanisme sistem rekrutmen yang digunakan Partai Demokrat lebih banyak menghasilkan "tokoh karbitan" dan saat sekarang cara ini tidak sesuai lagi dengan tingkat pendidikan dan daya nalar para pemilih. Di samping itu, persoalan-persoalan yang muncul bermuara pada bagaimana mekanisme sistem rekrutmen tersebut.

Menurut Rahman (2007: 104-105), klasifikasi partai politik dilihat dari segi komposisi dan fungsi keanggotaannya, secara umum dapat dilihat dari: Partai massa: mengutamakan kekuatan berdasarkan keunggulan jumlah anggota, Partai kader: ketaatan organisasi dan disiplin kerja dari anggota-anggotanya. Pimpinan partai biasanya menjaga kemurnian doktrin politik yang dianut dengan jalan mengadakan seleksi terhadap calon anggotanya dan memecat anggota yang menyeleweng dari garis partai yang telah ditetapkan.

Setiap organisasi apapun pasti memiliki tujuan tertentu, dimana tujuan tersebut akan menjadi penuntun serta pedoman ketika organisasi tersebut berjalan. Dalam mencapai tujuan tersebut harus dilaksanakan secara bersama-sama oleh orang-orang yang menjalankan organisasi tersebut, sehingga dalam pencapaian tujuan tersebut dapat membuahkan hasil yang sempurna. Begitu pula dengan partai politik yang memiliki tujuan yaitu untuk memperoleh kekuasaan di dalam pemerintahan.

Berdasarkan Undang-Undang Partai Politik Nomor 2 Tahun 2008 Pasal 10 tentang tujuan partai politik yang berbunyi;

\section{a. Tujuan Umum Partai Politik}

Mewujudkan cita-cita nasional bangsa Indonesia sebagaimana dimaksud dalam Pembukaan Undang-Undang Dasar Negara Republik Indonesia Tahun 1945, Menjaga dan memelihara keutuhan Negara Kesatuan Republik Indonesia, Mengembangkan kehidupan demokrasi berdasarkan Pancasila dengan menjunjung tinggi kedaulatan rakyat dalam Negara Kesatuan Republik Indonesia, dan Mewujudkan kesejahteraan bagi seluruh rakyat Indonesia.

b. Tujuan khusus Partai Politik

Meningkatkan partisipasi politik anggota dan masyarakat dalam rangka penyelenggaraan kegiatan politik dan pemerintahan, Memperjuangkan cita-cita Partai Politik dalam kehidupan bermasyarakat, berbangsa, dan bernegara, dan Membangun etika dan budaya politik dalam kehidupan bermasyarakat, berbangsa, dan bernegara.

Agar tujuan partai politik dapat diwujudkan dengan baik maka partai politik harus berfungsi dengan baik. Beberapa fungsi yang umumnya dipandang sebagai serangkaian fungsi partai politik yang dikemukakan oleh Adham (2007 : 29-30) sebagai berikut:

a. Sebagai sarana komunikasi politik

Salah satu fungsi partai politik adalah menyalurkan aneka pendapat dan aspirasi masyarakat serta mengaturnya agar kesimpangsiuran dalam masyarakat berkurang.

\section{b. Sebagai sarana sosialisasi politik}

Sosialisasi politik adalah proses seseorang memperoleh sikap dan orientasi atas fenomena politik yang berlaku umum dimasyarakat. Ini mencangkup antara lain proses penyampaian norma-norma dan nilai-nilai sosial dari generasi yang lebih tua kegenerasi yang lebih muda.

c. Sebagai rekrutmen politik

Fungsi ini adalah fungsi pencarian dan pengajakan orang berbakat untuk turut 
aktif dalam kegiatan politik sebagai anggota partai politik. Juga diusahakan menarik golongan muda yang memiliki kualifikasi tertentu untuk dididik sebagai kader guna menyosong kepemimpinan masa depan

\section{d. Sebagai pengatur konflik}

Dalam suasana demokrasi, persaingan dan perbedaan pendapat adalah wajar. Tidak ada demokrasi tanpa persaingan dan perbedaan pendapat. Namun demikian potensi perkembangannya menjadi konflik tetap terbuka dan harus diantisipasi sebaik mungkin. Maka dari itu partai politik berfungsi mengatur persaingan dan perbedaan tersebut sedemikian rupa sehingga tidak berkembang menjadi konflik.

Dalam Undang-Undang Partai Politik Nomor 2 Tahun 2008 tentang fungsi partai politik menegaskan adanya beberapa fungsi partai politik pada Pasal 11, sebagai sarana: 1) Pendidikan politik bagi anggota dan masyarakat luas agar menjadi warga negara indonesia yang sadar akan hak kewajibannya dalam kehidupan bermasyarakat, berbangsa dan bernegara; 2) Penciptaan iklim yang kondusif bagi persatuan dan kesatuan bangsa indonesia untuk kesejahteraan masyarakat; 3) Penyerap, penghimpun, dan penyalur aspirasi politik masyarakat dalam merumuskan dan menetapkan kebijakan negara; partisipasi politik warga negara indonesia; dan 4) Rekrutmen politik dalam proses pengisian jabatan politik melalui mekanisme demokrasi dengan memperhatikan kesetaraan dan keadilan gender.

Setiap organisasi tidak akan pernah terbentuk apabila tidak memiliki anggota, karena anggota merupakan penggerak roda setiap organisasi. Begitu pula dengan partai politik. Partai politik dituntut harus mampu melahirkan anggota-anggota legislatif yang berkualitas dan mengerti akan segala aspirasi masyarakat. Untuk menciptakan kader-kader yang berkualitas tersebut, partai politik harus menjalankan fungsinya dengan baik, terutama fungsi rekrutmen politik.

Dalam Undang-Undang Partai Politik Nomor 2 Tahun 2011 Pasal 29 tentang Rekrutmen Politik yang berbunyi bahwa parati politik melakukan rekrutmen terhadap Warga Negara Indonesia untuk menjadi : anggota partai politik; bakal calon anggota DPR dan DPRD: bakal calon Kepala Daerah dan Wakil Kepala Daerah; dan bakal calon Presiden dan Wakil Presiden. Rekrutmen bakal calon anggota DPR dan DPRD dilaksanakan melalui seleksi kaderisasi secara demokratis sesuai dengan AD dan ART dengan pertimbangan paling sedikit 30\% keterwakilan perempuan. Penetapan rekrutmen sebagaimana dimaksud di atas dilakukan dengan keputusan pengurus partai politik sesuai dengan AD dan ART.

Rekrutmen politik berasal dari dua kata yaitu rekrutmen dan politik. Rekrutmen berarti penyeleksian dan politik berarti urusan negara. jadi rekrutmen politik adalah penyeleksian rakyat untuk melaksanakan urusan negara. Menurut Kamus Besar Bahasa Indonesia rekrutmen politik adalah pemilihan dan pengangkatan orang untuk mengisi peran tertentu dalam sistem sosial berdasarkan sifat dan status (kedudukan), seperti suku, kelahiran, kedudukan sosial dan prestasi atau kombinasi dari kesemuanya (Rahman, 2007 : 246).

Mekanisme rekrutmen politik yang dilakukan partai politik terdiri dari dua sistem yaitu sistem terbuka dan sistem tertutup. Sistem terbuka akan memungkinkan lahirnya caloncalon legislatif yang betul-betul demokratis dalam melaksanakan tugas dan wewenangnya, hal ini dikarenakan oleh proses pengangkatan calon tersebut dilakukan secara terbuka. Sedangkan sistem tertutup merupa-kan kebalikan dari sistem terbuka, dimana para pemilih tidak mengenal seseorang calon legislatif, karena sistem pengangkatan calon legislatif tersebut dilakukan secara tertutup. Hal ini memungkinkan timbulnya calon legislatif yang tidak kompetitif, berhubung proses pengangkatan tidak diketahui oleh umum.

Kehadiran suatu partai politik dapat dilihat dari kemampuan partai tersebut melaksanakan fungsinya. Salah satu fungsi yang terpenting yang dimiliki partai politik adalah fungsi rekrutmen politik. Untuk itu partai politik memiliki cara tersendiri dalam melakukan pengrekrutan terutama dalam pelaksanaan sistem dan prosedural pengrekrutan yang dilakukan partai politik tersebut. 
Tak hanya itu proses rekrutmen juga merupakan fungsi mencari dan mengajak orang-orang yang memiliki kemampuan untuk turut aktif dalam kegiatan politik, yaitu dengan cara menempuh berbagai proses penjaringan.

\section{METODE PENELITIAN}

Penelitian ini dilakukan di Dewan Pimpinan Cabang (DPC) Partai Demokrat Kabupaten Polman Propinsi Sulawesi Barat. Lokasi ini di dasarkan atas pertimbangan bahwa lokasi tersebut merupakan asal daerah peneliti yang kemudian bertujuan untuk mengetahuai pola rekrutmen calon anggta legislatif yang dilakukan oleh DPC Partai Demokrat. Penelitian ini menggunakan metode penelitian deskriptif yang mencoba mengungkapkan dan menggambarkan pola rekrutmen anggota legislatif DPC Partai Demokrat Kabupaten Polman Provinsi Sulawesi Barat. Dalam penelitian ini yang menjadi populasi dalam penelitian ini adalah kader DPC Partai Demokrat Kabupaten Polman Provinsi Sulawesi Barat. Penentuan sampel dalam penelitian ini adalah ditentukan secara Purposive Sampling atau bertujuan dimana peneliti memilih informasi dan responden secara sengaja, yaitu mereka yang dianggap berkompetensi atau dianggap tahu pasti tentang pola rekrutmen politik DPC Partai Demokrat. Adapun informan terdiri dari 5 orang dan responden terdiri dari 30 orang yang ditetapkan sebagai sampel Informan : Ketua DPC Partai Demokrat, Sekretaris DPC Partai Demokrat Anggoata legislatif DPRD kabupaten polman fraksi Demokrat, Ketua tim penjaringan dan Koordinator divisi kaderisasi, pendidikan dan pelatihan cabang.

Sedangkan Responden Bakal calon anggota legislatif sebanyak 10 orang, Anggota tim penjaringan sebanyak 5 orang, Ketua DPAC sebanyak 5 orang dan Anggota DPC sebanyak 10 orang. Untuk memperoleh data dalam penelitian dikumpulkan dengan menggunakan beberapa teknis pengumpulan data sebagai berikut: Observasi, Kuesioner dan Wawancara. Data yang telah dikumpulkan selanjutnya dianalisis secara deskriptif kualitatif dengan cara pengelompokan data atau mengkategorisasikan data, yaitu data yang ada di tabulasi dengan memberikan bobot presentasi dan selanjutnya diinterpretasikan dengan memberikan uraian secara deskriptif sesuai dengan fakta atau keadaan yang ada di lokasi penelitian.

\section{HASIL PENELITIAN DAN PEMBAHASAN}

Pola Rekrutmen Calon Anggota Legislatif Oleh DPC Partai Demokrat di Kabupaten Polman Provinsi Sulawesi Barat

Partai Demokrat adalah sebuah partai yang merupakan institusi politik yang memiliki salah satu fungsi sebagai sarana rekrutmen politik, guna menghasilkan caloncalon pimpinan politik, untuk dipersiapkan menduduki jabatan legislatif melalui pemilu. Melalui rekrutmen politik, juga akan menjamin kontinuitas partai politik, dan kelestarian partai politik.

Dalam proses rekrutmen politik, terdapat dua mekanisme rekrutmen yaitu rekrutmen terbuka dan rekrutmen tertutup. Dalam rekrutmen terbuka, syarat dan prosedur untuk penjaringan calon anggota legislatif dapat diketahui secara umum, baik itu dari kader partai itu sendiri maupun masyarakat luas. Sedangkan dalam rekrutmen tertutup, syarat dan prosedur penjaringan calon anggota legislatif hanya kader partai politik itu sendiri yang mengetahui.

Hasil wawancara dengan Ketua DPC Partai Demokrat di Kabupaten Polman, mengenai pola rekrutmen calon anggota legislatif yang digunakan oleh Partai Demokrat:

"Partai Demokrat, pada level Kabupaten/ Kota di Kabupaten Polman menggunakan pola rekrutmen terbuka, dalam rekrutmen terbuka, terdapat dua mekanisme yaitu: pertama, merekrut calon anggota legislatif dari internal Partai Demokrat. Dalam mekanisme ini, Partai Demokrat mengakomodasi kader Partai yang menjadi pengurus Partai Demokrat, untuk direkrut sebagai calon anggota legislatif. Kedua, merekrut calon anggota dari eksternal Partai Demokrat. Dalam mekanisme ini, Partai 
Demokrat mengakomodasi non kader partai, yang tidak menjadi pengurus partai untuk direkrut sebagai calon anggota legislatif" ( $E$ K.25 Februari 2013).

Pola rekrutmen terbuka yang digunakan oleh Partai Demokrat sesuai yang dikatakan oleh Ketua DPC Partai demokrat Kabupaten Polman. Dimana Partai Demokrat merekret calon anggota legislatif dapat diketahui secara luas baik dari kader partai maupun dari masyarakat. Sesuai yang dikatakan oleh Putra yang dimana syarat dan prosedur untuk menampilkan seorang tokoh dapat diketahui secara luas, baik itu dari kader partai maupun dari masyarakat.

Tabel No. 1:

Tanggapan Responden Mengenai Pola Rekrutmen Terbuka yang digunakan oleh DPC Partai Demokrat di Kabupaten Polman (2003:209), mengenai rekrutmen terbuka,

Hasil wawancara dengan Sekretaris DPC Partai Demokrat Kabupaten Polman, mengenai pelaksanaan rekrutmen calon anggota legislatif:

"Pelaksanaan rekrutmen ini diawali dengan membentuk tim penjaringan yang biasanya diketuai oleh BAPILU (badan pemenangan pemilu). Tim penjaringan disini membuat pengumuman di media cetak untuk menginformasikan kepada seluruh masyarakat dan memberikan surat pemberitahuan kepada seluruh pengurus dan kader partai. Kemudian tim penjaringan menunggu pendaftaran dari semua bakal calon yang akan mendaftar. Semua berkas pendaftar akan diverifiksi dan diseleksi sesuai dengan persyaratan dari KPU. Pelaksanaan rekrutmen ini dilakuakan sesuai dengan petunjuk dari Juklak-Juknis yang dikeluarkan oleh DPP Partai Demokrat". (H B.28 Februari 2013).

Tabel No. 2 :

Tanggapan Responden Mengenai Pelaksanaan Rekrutmen Calon Anggota Legislatif

Sumber : Hasil olahan kuesioner 2013

Dari data diatas dapat disimpulkan bahwa tanggapan responden mengenai pola rekrutmen terbuka yang digunakan oleh DPC Partai Demokrat di Kabupaten Polman, responden yang menyatakan sangat baik 30\%, menyatakan baik, 36,66\%, menyatakan kurang baik $20 \%$, dan menyatakan tidak baik, 13,33\%.

Dalam melakukan rekrutmen calon anggota legislatif, DPC Partai Demokrat menggunakan pola rekrutmen terbuka dimana DPC Partai Demokrat mengyediakan dan memberikan kesempatan yang sama bagi seluruh warga negara untuk ikut bersaing dalam proses penyeleksian calon anggota legislatif. Pendaftaran calon anggota legislatif dibuka untuk internal dan eksternal partai yang berasal dari dalam dan luar Partai Demokrat.
Dari data diatas dapat disimpulkan bahwa tanggapan responden mengenai pelaksanaan rekrutmen calon anggota legislatif yang dilaksanakan oleh DPC Partai Demokrat di Kabupaten Polman, responden yang menyatakan sangat maksimal 6,66 \%, menyatakan maksimal $26,66 \%$, menyatakan kurang maksimal 36,66 $\%$, dan $30 \%$ menyatakan tidak maksimal. Pelaksanaan rekrutmen calon anggota legislatif masih kurang maksimal dikarenakan Partai Demokrat tidak melakukan rekrutmen secara sistematis. Partai lebih mengutamakan orangorang yang mempunyai pengaruh besar meskipun bukan kader partai sendiri.

Hasil wawancara dengan anggota legislatif DPRD Kabupaten Polman Praksi Demokrat 
tentang masalah yang terjadi dalam pelasanaan rekrutmen:

"Dalam melakukan perekrutan caleg masih didominasi oleh elit partai, Partai Demokrat tidak melakukan perekrutan calag secara sistematis, sehingga tidak mendapatkan caleg yang mempunyai kualifikasi berbeda-beda yang dibutuhkan untuk memperjuangkan program partai di parlemen, perekrutan caleg tidak dilakukan secara transparan, akuntabel, dan partisipatif" (S S, 5 Maret 2013).

Untuk menjadi anggota legislatif, lebih ditentukan oleh mekanisme pasar politik. Dimana konstituen hanya memilih calon anggota legislatif yang akan mencukupi atau memuaskan kebutuhan politik mereka. Kebutuhan politik yang dimaksud adalah kemampuan dari calon anggota legislatif tersebut, untuk merealisasikan janji-janji politiknya kepada konstituen, ketika benar-benar terpilih dan duduk sebagai anggota legislatif. Maka dari itu, pelaksanaan rekrutmen calon anggota legislatif ini harus lebih efektif.

Berdasarkan hasil wawancara dengan Sekretaris DPC Partai Demokrat di Kabupaten

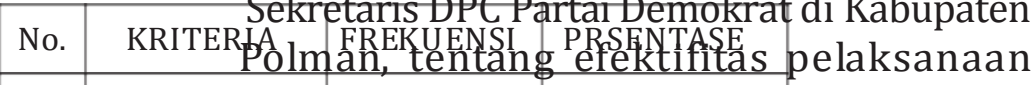

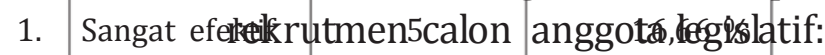

2. Efektif "Dibandingkan kepen, 2. pada tahun 2008, kepengurusan saat ini lebih 3. Kurang efektif

4. Tidak efektiakat tentang penerimaan zokn anggota legisJUMLAH latif, tapi dalam situasi $180 \%$ dialami Partai Demokrat pada akhir-akhir ini, banyak simpangsiur pemberitaan. Sehingga pada tahun 2013 ini kurang efektif dibandingkan pada tahun 2008 lalu. Pada tahun ini jumlah pendaftar bakal calon anggota legislatif lebih sedikit dibandingkan jumlah pendaftar pada tahun 2008 lalu. Tetapi dilihat sampai dengan sekarang ini pelaksanaan rekrutmen sudah cukup efektif karna semua dapil sudah terisi" (H B, 28 Februari 2013)

Tabel No. 3 :

Tanggpan responden tentang efektifitas pola rekrutmen calon anggota legislatif oleh DPC Partai Demokrat di Kabupaten Polman.
Sumber : Hasil olahan kuesioner 2013

Dari data diatas dapat disimpulkan bahwa tanggapan responden mengenai efektifitas pola rekrutmen calon anggota legislatif yang dilaksanakan oleh DPC Partai Demokrat di Kabupaten Polman, responden yang menyatakan sangat efektif $16,66 \%$, menyatakan efektif $26,66 \%$, menyatakan kurang efektif 36,66 \%, dan $20 \%$ yang menyatakan tidak efektif.

Partai Demokrat menggunakan pola rekrutemen terbuka, dimana Partai Demokrat merekrut calon anggota legislatif bukan hanya dari kader partainya saja, Partai Demokrat juga merekrut dari luar partai, seperti tokoh masyarakat, tokoh pemuda, tokoh perempuan dan bahkan pindahan kader partai lain. Maka dari itu, calon anggota legislatif yang akan maju pada pemilu 2014 nanti layak mandapatkan pendidikan dan pelatihan untuk menghadapi pemilu 2014. Jadi Partai Demokrat seharusnya mengadakan pendidikan dan pelatihan terhadap calon anggota legislatif yang diusung untuk persiapan pemilu nanti.

Hasil wawancara dengan Koordinator divisi kaderisasi, pendidikan dan pelatihan cabang DPC Partai Demokrat di Kabupaten Polman, tentang pendidikan dan pelatihan calon anggota legislatif:

"Setiap calon anggoata legislatif dari Partai Demokrat tidak diberikan pendidikan dan pelatihan, namun sebelum terpilih menjadi calon anggota legislatif di Partai Demokrat. Para calon anggota legislatif ini akan diberikan pelatihan dan pembekalan selama 3 hari tentang beberapa hal" (S B, 9 Maret 2013).

Tabel No. 4 :

Tanggapan Responden Tentang Pelatihan Dan Pembekalan Calon Anggota Legislatif Yang Akan Maju Pada Pemilu 2014. 
Tabel No. 4 :

Tanggapan Responden Tentang Pelatihan Dan Pembekalan Calon Anggota Legislatif Yang Akan Maju Pada Pemilu 2014.

Sumber : Hasil olahan kuesioner 2013

Dari data diatas dapat disimpulkan bahwa tanggapan responden mengenai pelatihan dan pembekalan calon anggota legislatif yang dilaksanakan oleh DPC Partai Demokrat di Kabupaten Polman, tidak ada responden yang menyatakan sangat efektif, yang menyatakan efektif 26,66 \%, menyatakan kurang efektif 40 $\%$, dan yang menyatakan tidak efektif $33,33 \%$.

Pelaksanaan pelatihan dan pembekalan calon anggota legislatif masih belum efektif dijalankan oleh Partai Demokrat. Pelaksanaan ini masih kurang efektif dikarenakan dalam Pelatihan dan pembekalan ini dilaksanakan hanya tiga hari dan hanya membahas mengenai platfrom partai, peta perpolitikan dan tata cara pemilihan umum. Seharusnya pelatihan dan pembekalan ini dilaksanakan jauh-jauh hari sebelum pemilu. Calon anggota legisltif seharusnya mendapatkan pendidikan politik yang lebih maksimal untuk menghadapi pemilihan umum legislatif. Dimana Partai Demokrat membutuhkan sumber daya manusia yang mumpuni dalam menghadapi pemilihan umum dalam melakukan kompetisi politik.

\section{Langkah-langkah yang Ditempuh Oleh} DPC Partai Demokrat Dalam Penetapan Calon Anggota Legislatif di Kabupaten Polman Propinsi Sulawesi Barat

Proses rekrutmen dalam penetapan calon anggota legislatif dilakukan melalui beberapa langkah-lankah yaitu:

\section{Persiapan}

Pada tahap persiapan ini kegiatan yang dilakukan oleh partai Demokrat yang membentuk sebuah tim penjaringan. Tugas-tugas tim khusus rekrutmen calon anggota legislatif tersebut diantaranya, menjaring calon anggota legislatif dari internal maupun eksternal partai atas dasar usulan dari bawah,menyusun kriteria calon anggota legislatif terutama dari sisi kompetensi dan keahlian, menentukan perbandingan calon anggota legislatif internal dan eksternal partai politik, serta menentukan syarat-syarat calon anggota legislatif yang objektif bebeas dari korupsi, grafikasi, kolusi maupun nepotisme.

Hasil wawancara dengan Ketua DPC Partai Demokrat Kabupaten Polman:

"Kami selaku pengurus DPC telah mempersiapkan segala sesuatu dalam penjaringan calon anggota legislatif ini, dimana kami telah membentuk tim penjaringan disertai dengan tugas-tugas yang akan diembang oleh tim ini. Bukan hanya itu, kami lebih pro aktif untuk mengajak kalangan masyarakat untuk ikut serta dalam proses rekrutmen ini" (E K, 12 Maret 2013).

\section{Pengumuman}

Pada tahap pengumuman ini Partai Demokrat melakukan pengumuman pendaftaran untuk bakal calon serta terbuka yang diumumkan melalui media massa dan surat pemberitahuan kepada seluruh pengurus, kader dan simpatisan sesuai dengan tingkatannya masing-masing.

Hasil wawancara dengan Ketua tim penjaringan calon anggota legislatif DPC Partai Demokrat di Kabupaten Polman:

"Ini adalah salah satu tugas kami sebagai tim penjaringan, disini kami harus pro aktif dalam mengumumkan kepada masyarakat dan seluruh kader-kader Partai Demokrat tentang pendaftaran yang kami buka sejak pertengahan bulan februari kemarin. Kami juga terjun langsung ke masyarakat untuk mengajak para tokoh-tokoh masyarakat yang kami anggap berkompeten"(A K, 18 Maret 2013).

\section{Pendaftaran}

Pada tahap pendaftaran ini para calon anggota legislatif diberikan formulir pendaftaran untuk kemudian diisi sesuai dengan 
data-data informasi tentang calon anggota legislatif yang diperlukan untuk kelengkapan administrasi.

Hasil wawancara dengan Ketua tim penjaringan calon anggota legislatif DPC Partai Demokrat di Kabupaten Polman:

"Dibandingkan pada tahun 2008 yang lalu, jumlah pendaftar pada tahun 2013 ini lebih sedikit, ini dimungkinkan karna adanya masalah-masalah yang terjadi di internal Partai Demokrat. Tetapi sekarang ini hampir semua dapil sudah terisi, yang awalnya hanya empat dapil, kemudian diubah menjadi lima dapil" (A K, 18 Maret 2013)

\section{Verifiksi}

Guna lebih menjamin berjalannya seleksi secara transparan atas dasar kriteria yang diterapkan Partai Demokrat, setiap pengurus partai pada masing-masing tingkatan partai yang memiliki kewenangan di dalam penjaringan. Pada tahap verifikasi ini kegiatan yang dilakukan adalah meneliti kebenaran dan keabsahan atau seluruh kelengkapan persyaratan bakal calon anggota legislatif, sebagaimana diatur dalam Anggaran Rumah Tangga dan peraturan Partai Demokrat yang mengatur mekanisme rekrutmen calon anggota legislatif.

Hasil wawancara dengan Sekretaris DPC Partai Demokrat Kabupaten Polman:

"Pada tahap verifikasi, bakal calon diseleksi melalui pemeriksaan berkas yang dipersyaratkan oleh Partai Demokrat. Persyaratanpersyaratan yang diterapkan oleh Partai Demokrat antara lain, mereka diwajibkan mengumpulkan 250 KTP pendukung, setelah itu ada persyaratan-persyaratan sesuai ketentuan KPU berupa SKCK (surat keterangan catatan kepolisian), surat keterangan kesehatan, surat keterangan domisili, dan surat keterangan terdaftar sebagai pemilih" (H B, 14 Maret 2013).

\section{Seleksi Khusus}

Pada tahap seleksi khusus ini Partai Demokrat melakukan kegiatan survei dan pengkajian terhadap nama-nama bakal calon anggota legislatif yang telah terjaring tersebut oleh suatu lembaga pengkajian profesional dan independen yang ditunjuk oleh DPP Patai
Demokrat akan untuk melakukan Fit and Proper Test (uji kepatutan dan kelayakan) tarhadap calon anggota legislatif dalam rangka mengetahui tingkat elektabilitas seluruh bakal calon yang diusulkan.

Hasil wawancara dengan Anggota DPRD Kabupaten Polman dari fraksi Demokrat:

"Ditahap seleksi ini semua bakal calon yang lolos verifikasi diuji kembali, apakah dia layak atau tidak untuk ikut berkompetisi. Tetapi di DPC Partai Demokrat sendiri belum sepenuhnya menerapkan seleksi ini, karna Partai Demokrat masih mengutamakan merekrut tokoh-tokoh masyarakat yang mempunyai basis massa yang banyak tanpa melalui seleksi ini" (S S, 20 Maret 2013).

\section{Penugasan}

Pada tahap penugasan ini Partai Demokrat akan memberikan penugasan kepada bakal calon anggota legislatif, antara lain meliputi pelaksanaan program:

a Melakukan rekrutmen anggota partai melalui kegiatan pemberian Kartu Tanda Anggota (KTA) oleh bakal calon anggota DPR, DPRD Provinsi, DPRD Kabupaten / Kota.

$b$. Membantu penyiapan tenaga saksi dan pelatihan saksi.

c. Melakukan program pemberdayaan masyarakat dan konstituen sesuai dengan bidang-bidang yang menjadi kebutuhan masyarakat dan konstituen.

Hasil wawancara dengan Ketua DPC Partai Demokrat Kabupaten Polman:

"Semua bakal calon anggota legislatif diberikan tugas untuk turun langsung ke masyarakat untuk bersosialisasi dan melakukan rekrutmen anggota partai yang nantinya akan diberi penilaian tersendiri" (E K, 12 Maret).

\section{Evaluasi dan penilaian akhir}

Pada tahap evaluasi dan penilaian akhir ini bakal calon anggota legislatif ditugaskan, memberikan evaluasi dan penilaian terhadap hasil kerja bakal calon anggota legislatif.

Hasil wawancara dengan Ketua tim penjaringan calon anggota legislatif DPC Partai Demokrat Kabupaten Polman: 
"Ditahap ini adalah penilaian akhir, dimana semua hasil kerja bakal calon anggota legislati dievaluasi kembali dan hail penilaian diserahkan sepenuhnya kepada pengus partai" (A K, 18 Maret 2013).

\section{Penetapan calon anggota legislatif}

Penetapan calon anggota legislatif dilakukan melalui rapat kerja partai, yang terdiri atas rapak kerja cabang, rapat kerja daerah, dan rapat kerja nasional, yang diadakan untuk menyaring bakal calon yang telah dievaluasi. Dalam hal ini, pengambilan keputusan untuk menetapkan calon anggota legislatif dilakukan dengan:

a. Pengambilan keputusan dalam rakercab, rakerda dan rakernas ditempuh melalui jalan musyawarah untukmencapai mufakat.

b. Dalam hal tidak tercapai kata mufakat, putusan diambil berdasarkan suara terbanyak.

c. Seluruh peserta yang hadir dalam rakercab, rakerda, dan rakernas memiliki hak suara dengan ketentuan satu peserta satu suara.

Partai Demokrat menetapkan calon anggota legislatif melalui beberapa langkahlangkah yaitu: persiapan, pengumuman, pendaftaran, verifikasi, seleksi khusus, penugasa, evaluasi dan penilaian akhir, dan penetapan calon anggota legislatif. Semua langkah-langkah yang ditempuh oleh Partai Demokrat ini berdasrkan peraturan Parta Demokrat yang mengatur mekanisme rekrutmen calon anggota legislatif. Namun dalam langkah-langkah ini masih ada yang belum diterapkan sepenuhnya oleh Partai Demokrat seperti seleksi khusus. Partai Demokrat lebih mengutamakan tokoh-tokoh masyarakat yang mempunyai basis massa yang banyak tanpa melalui seleksi khusus ini.Dalam proses rekrutmen ini, Partai Demokrat dalam memilih dan menetapkan calon anggota legislatif, faktor yang paling dominan dalam merekrut calon anggota legislatif adalh faktor ketokohan dimana seorang calon anggota legislatif itu pada umumnya mempunyai basis massa yang banyak yang sudah dikenal oleh masyarakat luas dan mampu mendokrak suara partai pada saat pemilihan umum nanti.

\section{E. KESIMPULAN}

Pola rekrutmen calon anggota legislatif oleh DPC Partai Demokrat di Kabupaten Polman Provinsi Sulawesi Barat menggunakan pola rekrutmen terbuka. Dalam rekrutmen terbuka terdapat dua mekanisme : Pertama, merekrut calon anggota legislatif di internal partai. Dalam mekanisme ini, Partai Demokrat mengakomodasi kadernya yang menjadi pengurus di partai untuk direkrut sebagai calon anggota legislatif. Kedua, merekrut calon anggota legislatif di eksternal partai. Dalam mekanisme ini, Partai Demokrat mengakomodasi non kader partai untuk direkrut sebagai calon anggota legislatif, seperti tokoh masyarakat dan para simpatisan. Namun dalam sistem rekrutmen Partai Demokrat belum berjalan secara efektif. Hal ini terbukti dengan masih adanya masalah-masalah yang terjadi dalam proses rekrutmen calon anggota legisltif. Adapun masalah yang terjadi dalam rekrutmen calon anggota legislatif yaitu melakukan perekrutan calon anggota legislatif masih didominasi elit partai. Partai Demokrat tidak melakukan perekrutan secara sistematis, sehingga tidak menadaptkan calon anggota legislatif yang mempunyai kualifikasi berbedabeda yang dibutuhkan untuk memperjuangkan program partai di parlemen. Perekrutan calon anggota legislatif tidak dilakukan secara trasparan, akuntabel dan partisipatif.

Langkah-langkah yang ditempuh oleh DPC Partai Demokrat dalam penetapan calon anggota legislatif di Kabupaten Polman Provinsi Sulawesi Barat yaitu persiapan, pengumuman, pendaftaran, verifikasi, seleksi khusus, penugasan, evaluasi dan penilaian akhir, penetapan calon anggota legislatif. Semua langkah-langkah ini berdasarkan peraturan Partai Demokrat yang mengatur mekanisme rekrutmen calon anggota legislatif. Partai Demokrat masih belum maksimal dalam menjalankan langkah-langkah penetapan calon anggota legislatif. Proses rekrutmen calon anggota legislatif Partai Demokrat lebih memperioritaskan tokohtokoh masyarakat yang mempunyai basis massa. Faktor ketokohan adalah faktor yang paling dominan dalam memasang seorang calon anggota legislatif yang pada umumnya calon ini sudah dikenal oleh masyarakat luas. 


\section{DAFTAR PUSTAKA}

Adham, Noor, S.H., M.H. (2007). Sumbangan Perusahaan Untuk Partai - Perspektif Undang-Undang No. 1 Tahun 1995 tentang Perseroan terbatas. Bandung: Mandar Maju

Budiardjo, Miriam. 2008. Dasar-Dasar Ilmu Politik (Edisi Revisi). Jakarta : Gramedia Pustaka Ilmu,

Firmanzah, Ph.D, 2011. Mengelola Partai Politik - Komunikasi dan Positioning Ideologi Politik di Era Demokrasi, Jakarta : Yayasan Pustaka Obor Indonesia.

Ihsan, A. Bakri. 2012. Politik tak Hanya Kekuasaan - Sisi Lain Kepemimpinan Presiden SBY. Jakarta : Expose

Kumpulan Sejarah. 2012. Sajarah Partai Demokrat. http://pacitan.demokrat.or.id/ sejarah//html. diakses 11okober 2012

Pramono, Agus, 2005. Elit Politik: Yang Loyo dan Harapan Masa Depan, Yogyakata : Pustaka Sinar Harapan

Prudjung, Chang. 2010. Rekrutmen Politik. http://Rekrutmen-Politik.html. diakses 12 November 2012

Putra, Fadillah. 2003. Partai Politik dan Kebijakan Publik, Yogyakarta : Pustaka Pelajar.

Rahman, A. H.I. 2007. Sistem Politik Indonesia, .Yogyakarta : Graha Ilmu

Rumahpemilu. 2012. Calon Anggota Legislatif. Http://Calonanggotalegislatif//Html. diakses 26 september 2012

Sitepu, P. Antonius. 2012. Studi Ilmu Politik. Yogyakarta : Graha Ilmu

Syafiie, Kencana, M.Si \& Azhari, SSTP. 2010. Sistem Politik di Indonesia Bandung : Refika Aditama
Syafiie, Kencana, M.Si. 2012. Etika Politik. Bandung : Pustaka Reka Cipta

Syarbaini, Dr. Syahtrial. M.A. dkk. 2011. Pengetahuan Dasar Ilmu Politik, Bogor : Ghalia Indonesia.

Tifiacerdikia. Learning. 2012. Pengertian RekrutmenPolitik. http://pengertian rekrutmenpolitik.html. di akses 12 November 2012.

Tobing, S.G, Andika. 2009. Kaderisasi dan Penetapan Caleg Partai politik. Skripsi. (Tidak Dipublikasikan) FISIP Universitas Sumatra Utara Medan.

Usman, Husain. \& Purnomo Setiady Akbar. 2009. Metodologi Penelitian Sosial. Jakarta : Bumi Aksara

\section{DOKUMEN - DOKUMEN:}

Undang-Undang Republik Indonesia Nomor 2 Tahun 2008, tentang Partai Politik.

Undang-Undang Republik Indonesia Nomor 2 Tahun 2011, tentang Partai Politik.

Undang-Undang Republik Indonesia Nomor 8 Tahun 2012, tentang Pemilihan Umum Anggota DPR, DPD, dan DPRD

Arsip DPC Partai Demokrat

Dewan Pimpinan Pusat Partai Demokrat. Program Umum Partai Demokrat 2010 $-2015$

Petunjuk Pelaksanaan dan Petunjuk Teknis (Juklak-Jukis) Mekanisme Penjaringan Bakal Calon Anggota Legislatif (DPR-RI, DPRD Provinsi dan DPRD Kabupaten/ Kota) Partai Demokrat Periode 20142019 